\title{
Seasonal variability of planktonic copepods (Copepoda: Crustacea) in a tropical estuarine region in Brazil
}

\section{Cristina de Oliveira Dias ${ }^{1,}$; Adriana Valente de Araujo ${ }^{1} \&$ Sérgio Luiz Costa Bonecker ${ }^{1}$}

\author{
1 Universidade Federal do Rio de Janeiro, Instituto de Biologia, Departamento de Zoologia, Laboratório Integrado de \\ Zooplâncton e Ictioplâncton. Cidade Universitária, CCS, Bloco A, 21941-590 Rio de Janeiro, Rio de Janeiro, Brasil. \\ 2 Corresponding author. E-mail: crcldias@hotmail.com
}

\begin{abstract}
The Caravelas River estuary and adjacent coastal region were studied during the rainy and dry seasons of 2003-2004 to assess the copepod community structure. Abiotic and biotic parameters were measured, and the total density, frequency and percentage of copepod taxa were determined for each sampling period. Copepod densities showed significant differences between sampling periods, with higher densities in the rainy seasons (Mean: $90,941.80$ ind. $\mathrm{m}^{-3}$; S.D.: 26,364.79). The sampling stations located to the north and south, in the coastal region adjacent to the Caravelas River estuary presented the lowest copepod density values. The copepod assemblage was composed mainly of estuarine and estuarine/coastal copepods. The seasonal variations in temperature and salinity influenced the abundance of species during the rainy and dry seasons, with the following dominant species alternating: Paracalanus quasimodo Bowman, 1971 in the rainy season of 2003, Parvocalanus crassirostris Dahl, 1894 in the dry season of 2003 and Acartia lilljeborgii Giesbrecht, 1892 in the rainy and dry seasons of 2004. Non-parametric multidimensional scaling indicated differences in copepod assemblages between sampling periods, but not between sampling stations.

KEY WORDS. Coastal region; Northeast Brazil; Seasonal variability; Tropical zone; Zooplankton.
\end{abstract}

In aquatic ecosystems, copepods are generally the most important component of the mesozooplankton in terms of abundance, biomass and diversity, and serve as an important link by transferring energy and organic materials between primary producers (phytoplankton) and animals of higher trophic levels such as planktivorous fish and carnivorous invertebrates (Ara 2004, SHimode et al. 2006). Spatial-temporal studies of copepod diversity and abundance are fundamental to assess their contribution to the production and flow of particulate and dissolved organic materials, as well as their role in estuary trophodynamics (PerissinotTo et al. 2003, Magalhães et al. 2006).

In tropical oceans, community seasonal dynamics are difficult to identify and are much less pronounced than those observed in temperate aquatic ecosystems. Seasonal variations recorded in tropical and sub-tropical coastal regions are mainly determined by the local influence of the rainy and dry seasons and by regional oceanographic phenomena. These phenomena derive from singular or irregular events, in contrast to those observed in temperate and polar seas, where biomass variations along the year are more predictable (NyBAKKEN \& BERTNESS 2005).

In the southwest Atlantic, on the Brazilian northeastern coast, the coastal zone of Caravelas (Bahia) contains diverse and productive ecological systems, including the Abrolhos coral reefs, considered the most important coral reef complex in the
South Atlantic Ocean. In this region, ecotourism and recreation compete with the extensive, uncontrolled and exploitative local fishery, urban expansion, port construction, industries (paper mills), forestry, and fossil fuel exploration (ANDRADE \& Dominguez 2002, Anp 2009).

As many other areas along the Brazilian coast (ANP 2009), the region between the border of the states of Bahia and Espírito Santo and Prado city (state of Bahia), where the Mucuri mangrove and Caravelas Bay are located, is poorly studied, as are other areas along the Brazilian coast (ANP 2009). Zooplankton studies in these areas have dealt with aspects of the population and/or community structure, spatial distribution and seasonal variation in abundance (GAUdy 1963, SEgUin 1965, Valentin \& Monteiro-Ribas 1993, Neumann-Leitão 1995, Rap 2009); of these, none was carried out in the Caravelas region.

This study describes the occurrence, abundance patterns, and seasonal distribution of copepods in the estuary of the Caravelas River and the adjacent coastal region, from data collected in the dry and rainy seasons of 2003-2004. Three questions were addressed: 1) Are there different copepod assemblages in the studied area? 2) How are the local copepod assemblages influenced by the dry and rainy seasons? 3) How do environmental, temporal and spatial factors contribute to the observed patterns? 


\section{MATERIAL AND METHODS}

The Caravelas coastal region is located in northeastern Brazil. The Caravelas strandplain has an area of approximately $800 \mathrm{~km}^{2}$ and is bordered by the Tablelands of the Barreiras Formation (Upper Tertiary). It has a wide continental shelf, extending up to $246 \mathrm{~km}$ offshore. Its Quaternary evolution was strongly determined by relative sea-level changes. Contrary to other strandplains along the east coast of Brazil, such as the Jequitinhonha (Bahia) and the Doce (Espírito Santo), situated respectively north and south of Caravelas, the Caravelas has no association with a major river (ANDRADE et al. 2003).

The Caravelas River estuary $\left(17^{\circ} 44^{\prime}-17^{\circ} 53^{\prime} \mathrm{S}, 39^{\circ} 04^{\prime}-39^{\circ}\right.$ $12^{\prime} \mathrm{W}$ ) is located in southern Bahia (Fig. 1), and is 3,800 $\mathrm{m}$ long, 90 $\mathrm{m}$ wide and up to $5 \mathrm{~m}$ deep (LEÃo \& Dominguez 2000). This system is highly dynamic, influenced directly by the Caravelas River and indirectly by the Brazil Current. The estuarine zone is bordered by a $66.44 \mathrm{~km}^{2}$ long mangrove forest (LEÃo 1999). In the Caravelas River estuary, continental waters do not greatly influence the adjacent coastal region, because the Caravelas Channel is not a river, but rather a large drainage channel for the mangroves.

The area is located on the east coast of Brazil, where the climate is humid, with a mean temperature ranging between $24^{\circ} \mathrm{C}$ in winter and $27^{\circ} \mathrm{C}$ in summer (MARCHIORO et al. 2005). The region has a typical tropical precipitation regime, usually with a rainy season in spring and summer (November-April) and a dry season in winter (May-October).

The specimens examined were obtained as part of a major study of the zooplankton fauna off northeastern Brazil. Zooplankton sampling was carried out during one day at seven different sites along the coast of Bahia during the ebb-flood tide, in the dry (February 2003 and May 2004) and rainy (October 2003 and 2004) seasons. These sites are located in the estuarine zone of the Caravelas River (stations P1 and P2) and the adjacent coastal region out to the $10-\mathrm{m}$ isobath (stations P3, P4, P5, P6 and P7) (Fig. 1).

Precipitation data were obtained from Andrelina L. dos Santos of the Agência Nacional de Águas (ANA).

The samples were collected by horizontal hauls, with three net hauls performed at each station, totalling 84 samples. A cylindrical-conical net of mesh size $200 \mu \mathrm{m}$ and mouth diameter $60 \mathrm{~cm}$, fitted with a calibrated flowmeter, was used. The haul time averaged five minutes. Samples were fixed and preserved in $4 \%$ buffered formalin.

The samples were divided into fractions with a Folsom Plankton Sample Splitter (McEwEn et al. 1957), and replicate subsamples containing at least 100 copepods were taken for analysis (Frontier 1981). Copepods were identified to species whenever possible, according to BradFord-Grieve et al. (1999) and Dias \& Araujo (2006). Taxon abundance per cubic meter and copepod species composition were determined for all samples. The mean total density of each species was estimated from adults and copepodites in the three replicate samples. Shannon's diversity index (SHANNON 1948) was calculated to evaluate the degree of organization of the copepod community, and evenness was calculated according to PIELOU (1977).

All the specimens collected were deposited in the copepod collection of the Integrated Zooplankton and Ichthyoplankton Laboratory of the Federal University of Rio de Janeiro (DZUFRJ 0001-0145, DZUFRJ 0391-0571, DZUFRJ 1957-2124, DZUFRJ 3245-3441).

Temperature $\left({ }^{\circ} \mathrm{C}\right)$, salinity (reported following the Practical Salinity Scale) and dissolved oxygen (mg. $\left.\mathrm{l}^{-1}\right)$ were measured using a Hydrolab CTD (Quanta). In order to analyze these parameters, two depths were chosen: at the surface $(0.5 \mathrm{~m})$ and near $(0.5 \mathrm{~m}$ above) the bottom, which covered the area sampled by the net. Surface-water samples $(0.5 \mathrm{~m})$ for spectrophotometric determination of the chlorophyll $a\left(\mathrm{mg} . \mathrm{m}^{-3}\right)$ concentration (LORENZEN 1967) were taken with a Niskin bottle.

Analysis of variance (ANOVA) was used at a significance level of $p<0.05$ to identify statistical differences between the two sample series (rainy and dry seasons) and among the stations. All data were evaluated for normality and homogeneity prior to analysis. The post-hoc test was used to identify the differences among the collections when statistical differences were found.

Cluster Analysis and Multi-dimensional Scaling (MDS) were carried out using the program package Primer 5 . The data were $[\log (\mathrm{x}+1)]$-transformed. A similarity matrix was constructed using species with occurrences higher than $14 \%$ at the seven stations in the two years of sampling. Hierarchical agglomerative clustering was carried out using the Bray-Curtis similarity index coupled with group average linkage to produce a dendrogram depicting clusters of stations based on the total density. An MDS was used to classify stations with different copepod community structures. The stress value of representation lower than 0.1 represented good ordinations with a low risk of misinterpretation of the data. Analysis of similarity (ANOSIM) was used to test for significant differences in copepod assemblage structure between sampling years and sampling stations. The SIMPER test (similarity percentages) was used to identify the species that accounted for most of the similarities within groups.

Correlations between the biotic and environmental variables (temperature, salinity, dissolved oxygen and chlorophyll $a$ at the surface and near the bottom) were estimated using the Pearson r-index.

\section{RESULTS}

\section{Environmental data}

Three water masses were recognized in the estuary of the Caravelas River and the adjacent coastal region during the entire sampling period (2003-2004), at the two depths measured: Tropical Water (TW - temperatures $>20.0^{\circ} \mathrm{C}$ and salinities $>36.0$ ), Mixed Water (MW - temperatures $>20.0^{\circ} \mathrm{C}$ and salinities from 34.5 to 36.0), and Coastal Water (CW - temperatures $>20.0^{\circ} \mathrm{C}$ and salinities <34.5) (Figs 2 and 3). The Mixed Water (MW) is the result of mixing of the Tropical Water (TW) and the continental drainage (Coastal Water - CW). 


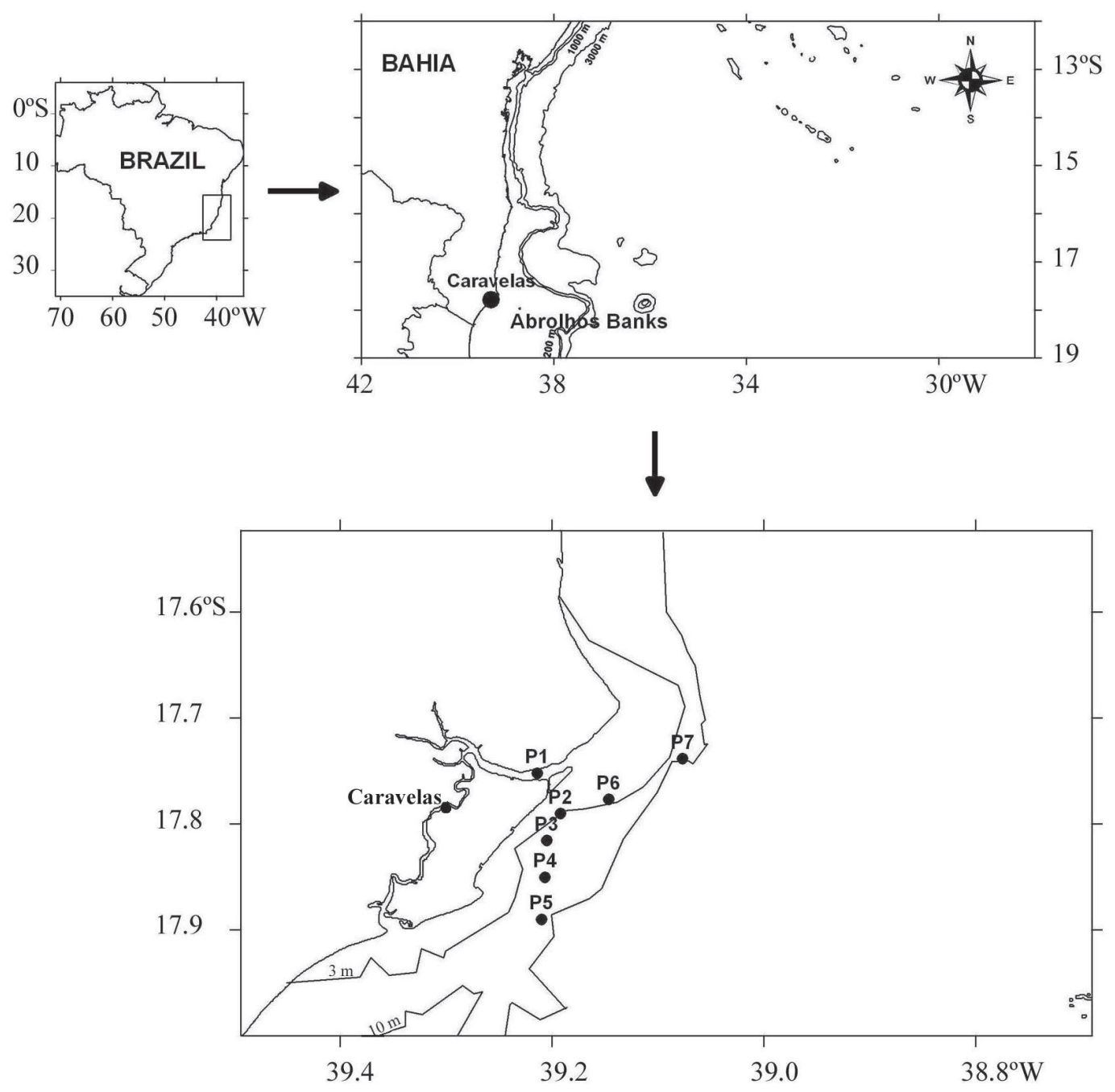

Figure 1. Study area and sampling stations in the Caravelas River estuary and adjacent coastal region.
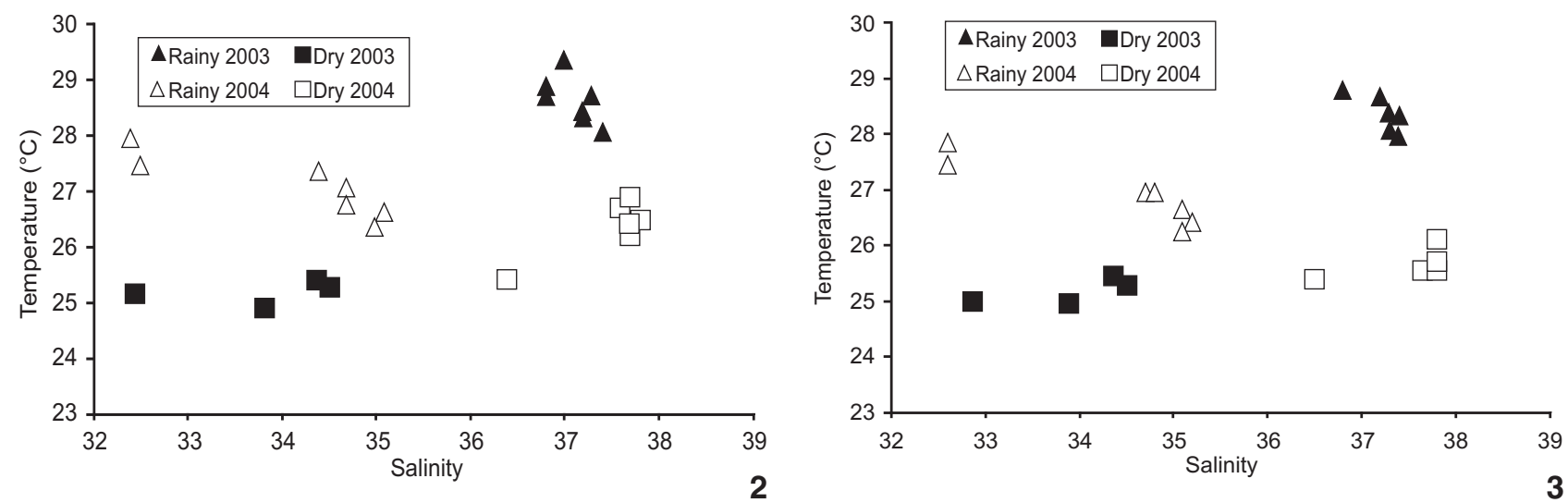

Figures 2-3. Temperature-salinity diagram of the water masses observed in the Caravelas River estuary and the adjacent coastal region: (2) surface; (3) near the bottom. 
The hydrographic parameters differed between the cruises (rainy and dry season 2003-2004). The presence of the CW was observed during the 2003 dry season and the 2004 rainy season, with a mean salinity of 34.10 (S.D.: 0.78) and 34.11 (S.D.: 1.16) at the surface, and 34.17 (S.D.: 0.61) and 34.30 (S.D.: 1.18) near the bottom, respectively (Tab. I). The lowest mean temperatures were observed during the 2003 dry season, with a mean of $25.24^{\circ} \mathrm{C}$ (S.D.: 0.17) at the surface, and $25.21^{\circ} \mathrm{C}$ (S.D.: 0.18) near the bottom. The occurrence of the CW was observed at all the stations of the Caravelas River estuary and the adjacent coastal region, during the 2003 dry season, and at stations P1 and P2, which were located at the entrance of the Caravelas River estuary, during the 2004 rainy season, mainly at ebb tide.

The occurrence of the MW was observed during the 2004 rainy season, at the stations located in the coastal region adjacent to the Caravelas River (stations P3 to P7) (Tab. I).

In the 2003 rainy and 2004 dry seasons, the presence of the TW was observed at all stations in the study area. The mean temperature at the surface was $28.65^{\circ} \mathrm{C}$ (S.D.: 0.42) and $26.40^{\circ} \mathrm{C}$ (S.D.: 0.50), and near the bottom was $28.40^{\circ} \mathrm{C}$ (S.D.: 0.32) and $25.64^{\circ} \mathrm{C}$ (S.D.: 0.23 ), respectively in the rainy and dry seasons (Tab. I). The mean salinity was 37.10 (S.D.: 0.24) at the surface, and 37.17 (S.D.: 0.26) near the bottom, in the 2003 rainy season, and 37.50 (S.D.: 0.50) at the surface, and 37.60 (S.D.: 0.49) near the bottom, in the 2004 dry season.

The dissolved oxygen concentration ranged from 5.95 to $7.54 \mathrm{mg} . \mathrm{l}^{-1}$ at the surface, and 5.61 to $8.00 \mathrm{mg} . \mathrm{l}^{-1}$ near the bottom (Tab. I). Higher values were observed in the 2003 rainy

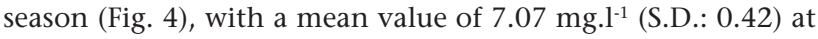
the surface, and $7.23 \mathrm{mg} . \mathrm{l}^{-1}$ (0.63) near the bottom.

Chlorophyll $a$ concentrations ranged between 0.0004 and $0.0249 \mathrm{mg} \cdot \mathrm{m}^{-3}$ at the surface, and 0.0004 and $0.0369 \mathrm{mg} \cdot \mathrm{m}^{-3}$ near the bottom (Tab. I).

Precipitation did not follow the normal pattern (rainy summer and dry winter); i.e., during the study period there was no distinct dry or rainy season. During the sampling months the values were below $72 \mathrm{~mm}$ (2003 rainy - $32.1 \mathrm{~mm}, 2003$ dry - $65.3 \mathrm{~mm}, 2004$ rainy $-45.2 \mathrm{~mm}$ and 2004 dry $-71.4 \mathrm{~mm}$ ).

\section{The copepod assemblages}

The overall mean of the total copepod density was 45,620 ind. $\mathrm{m}^{-3}$ (S.D.: 40,496), with abundance peaks (up to a mean of 40,000 ind. $\mathrm{m}^{-3}$ ) in the 2003-2004 rainy season. The copepod density differed between sampling periods $(\mathrm{p}<0.05)$. The highest density was recorded during the 2004 rainy season (Mean: 90,942 ind.m ${ }^{-3}$; S.D.: 26,365) (Fig. 5).

Table I. Minimum, maximum, mean and standard deviation of the salinity, temperature $\left({ }^{\circ} \mathrm{C}\right)$, dissolved oxygen $\left(\mathrm{mg} . \mathrm{I}^{-1}\right)$ and $\mathrm{Chlorophyll}$ $a\left(\mathrm{mg} \cdot \mathrm{m}^{-3}\right)$ of the sampling stations during the entire sampling period in the Caravelas River estuary and the adjacent coastal region.

\begin{tabular}{|c|c|c|c|c|c|c|c|c|c|c|c|c|c|c|}
\hline \multirow{2}{*}{ Parameters } & \multicolumn{2}{|c|}{ Station 1} & \multicolumn{2}{|c|}{ Station 2} & \multicolumn{2}{|c|}{ Station 3} & \multicolumn{2}{|c|}{ Station 4} & \multicolumn{2}{|c|}{ Station 5} & \multicolumn{2}{|c|}{ Station 6} & \multicolumn{2}{|c|}{ Station 7} \\
\hline & \multicolumn{2}{|c|}{$\overline{\text { Surface Bottom }}$} & \multirow[t]{2}{*}{ Surface } & \multirow[t]{2}{*}{$\overline{\text { Bottom }}$} & \multirow[t]{2}{*}{ Surface } & \multirow[t]{2}{*}{$\overline{\text { Bottom }}$} & \multicolumn{2}{|c|}{$\overline{\text { Surface Bottom }}$} & \multicolumn{2}{|c|}{$\overline{\text { Surface Bottom }}$} & \multicolumn{2}{|c|}{$\overline{\text { Surface Bottom }}$} & \multirow{2}{*}{\multicolumn{2}{|c|}{$\overline{\text { Surface Bottom }}$}} \\
\hline sainity & & & & & & & & & & & & & & \\
\hline Min & 32.40 & 32.60 & 32.50 & 32.60 & 34.37 & 34.37 & 34.51 & 34.51 & 34.51 & 34.51 & 34.40 & 34.51 & 34.51 & 34.51 \\
\hline Max & 36.80 & 36.80 & 37.80 & 37.80 & 37.70 & 37.80 & 37.60 & 37.80 & 37.60 & 37.70 & 37.70 & 37.80 & 37.70 & 37.80 \\
\hline Mean & 34.51 & 34.69 & 35.23 & 35.28 & 35.94 & 36.04 & 36.13 & 36.20 & 36.08 & 36.15 & 36.00 & 36.10 & 36.03 & 36.20 \\
\hline S.D. & 42 & 27 & 2.48 & .43 & 1.66 & 1.71 & 1.55 & 1.59 & 1.55 & 1.58 & 1.79 & 1.74 & 1.66 & 1.64 \\
\hline \multicolumn{15}{|l|}{ Temperature } \\
\hline Min & .16 & 24.98 & 24.90 & 24.94 & 25.41 & 25.44 & 25.31 & 25.33 & 25.28 & 25.26 & 25.30 & 25.25 & 25.30 & 25.25 \\
\hline Max & 28.71 & 28.74 & 28.88 & 28.74 & 29.37 & 28.62 & 28.72 & 28.37 & 28.45 & 28.02 & 28.09 & 27.96 & 28.30 & 28.32 \\
\hline Mean & 26.79 & 26.73 & 26.92 & 26.80 & 27.00 & 26.67 & 26.83 & 26.43 & 26.68 & 26.25 & 26.90 & 26.40 & 26.68 & 26.47 \\
\hline S.D. & 1.78 & 1.83 & 1.67 & 1.64 & 1.71 & 1.45 & 1.41 & 1.37 & 1.32 & 1.25 & 1.17 & 1.27 & 1.24 & 1.36 \\
\hline \multicolumn{15}{|c|}{ Dissolved oxygen } \\
\hline Min & 5.95 & 5.71 & 6.03 & 5.61 & 6.09 & 5.89 & 6.12 & 5.90 & 6.15 & 5.77 & 6.25 & 5.95 & 6.14 & 6.03 \\
\hline Max & 6.39 & 6.35 & 6.65 & 6.46 & 7.06 & 7.16 & 7.40 & 8.00 & 7.10 & 7.38 & 7.37 & 7.49 & 7.54 & 7.79 \\
\hline Mean & 6.18 & 6.05 & 6.36 & 6.14 & 6.54 & 6.31 & 6.61 & 6.54 & 6.53 & 6.42 & 6.61 & 6.41 & 6.55 & 6.56 \\
\hline S.D. & 0.19 & 0.27 & 0.26 & 0.37 & 0.49 & 0.57 & 0.58 & 0.98 & 0.43 & 0.69 & 0.52 & 0.73 & 0.67 & 0.83 \\
\hline \multicolumn{15}{|l|}{ Chlorophyll a } \\
\hline Min & 0.0000 & 0.0008 & 0.0018 & 0.0006 & 0.0015 & 0.0006 & 0.0004 & 0.0006 & 0.0004 & 0.0000 & $0.0004 c$ & 0.0004 & 0.0000 & 0.0012 \\
\hline Max & 0.0043 & 0.0041 & 0.0249 & 0.0369 & 0.0078 & 0.0099 & 0.0036 & 0.0064 & 0.0021 & 0.0008 & 0.0043 & 0.0050 & 0.0021 & 0.0014 \\
\hline Mean & 0.0011 & 0.0019 & 0.0067 & 0.0097 & 0.0023 & 0.0030 & 0.0010 & 0.0018 & 0.0006 & 0.0002 & 0.0012 & 0.0020 & 0.0005 & 0.0007 \\
\hline S.D. & 0.0022 & 0.0019 & 0.0122 & 0.0181 & 0.0037 & 0.0047 & 0.0017 & 0.0031 & 0.0010 & 0.0004 & 0.0021 & 0.0021 & 0.0011 & 0.0008 \\
\hline
\end{tabular}



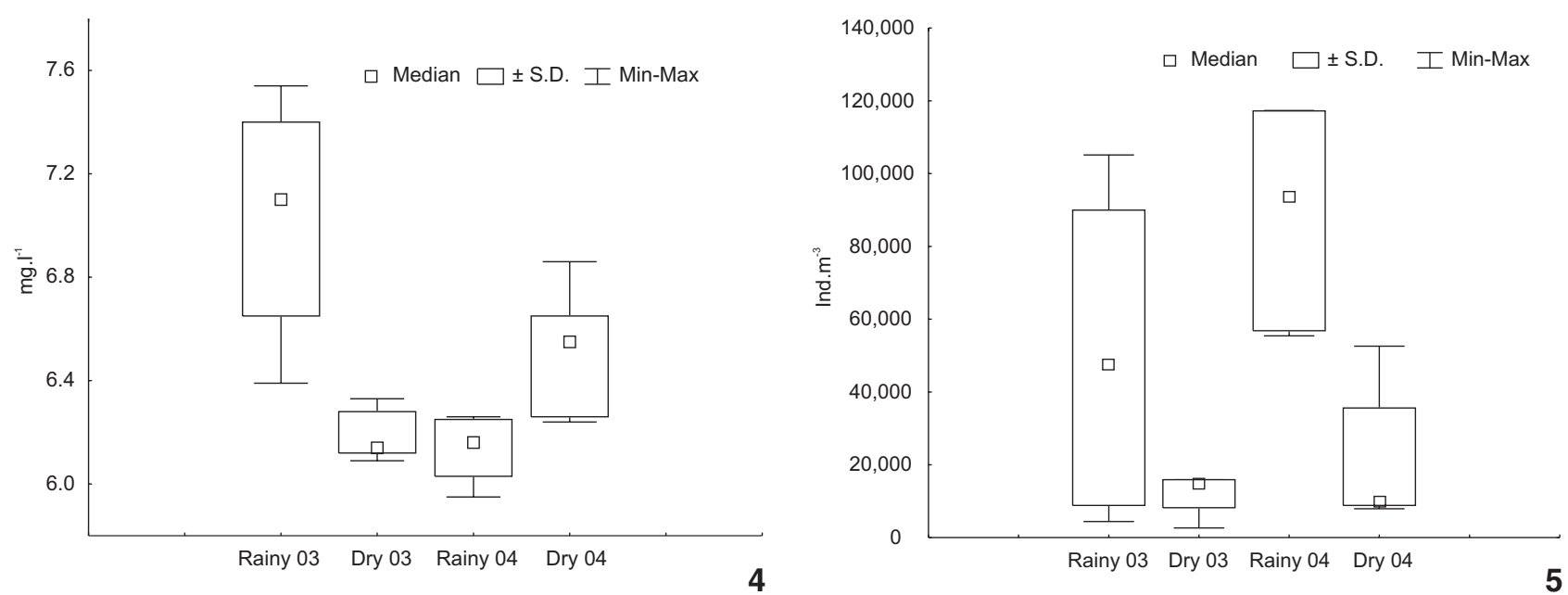

Figures 4-5. (4) Dissolved oxygen concentrations (Mg. $\mathrm{I}^{-1}$ ) observed in the Caravelas River estuary and the adjacent coastal region during the sampling periods. (5) Seasonal mean, standard deviation, and minimum and maximum variation in the density of the copepod community (Ind. $\mathrm{m}^{-3}$ ) in the Caravelas River estuary and the adjacent coastal region during the sampling periods.

In relation to the sampling stations, copepod density ranged between 2,652 ind. $\mathrm{m}^{-3}$ (station P7, north of the Caravelas River) during the 2003 dry season, and was higher than 117,000 ind.m ${ }^{3}$ (station P4 south of the Caravelas River, and station P6 north of the Caravelas River) during the 2004 dry season (Fig. 6). Overall copepod density differed among the sampling stations $(\mathrm{p}<0.05)$.

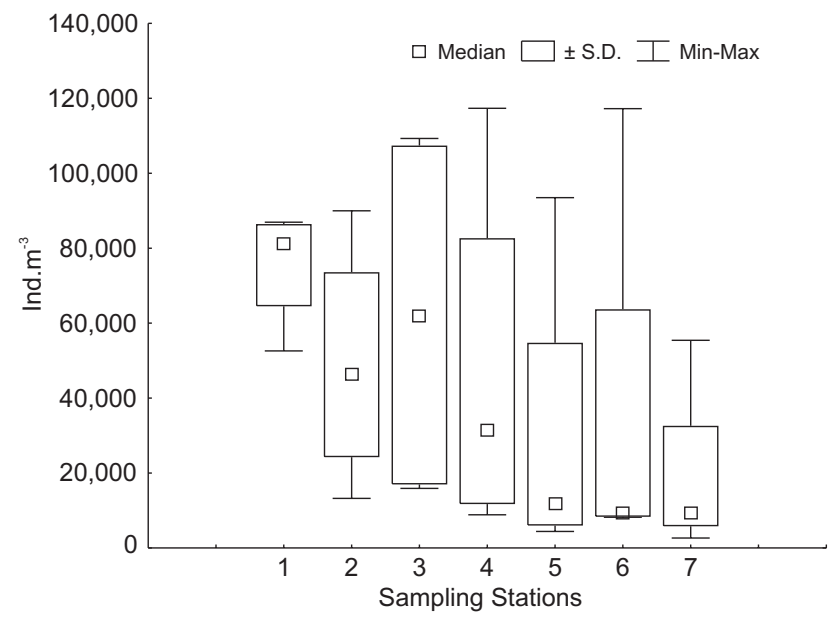

Figure 6. Seasonal mean, standard deviation, and minimum and maximum variation of the copepod density (Ind. $\mathrm{m}^{-3}$ ) at the sampling stations in the Caravelas River estuary and the adjacent coastal region.

The Cluster Analysis grouped the stations located in the Caravelas River (station P1), near the mouth of the river (station P2) and to the south (stations P3 and P4), separated from those located in the adjacent coastal region to the north (stations P6 and P7) and south (station P5), near the 10-m isobath, which showed the lowest copepod densities (Fig. 7).

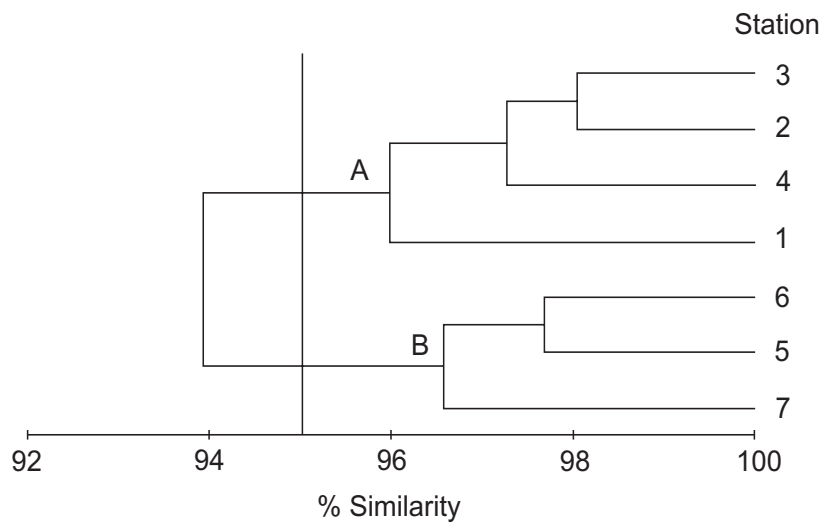

Figure 7. Cluster Analysis of the total copepod density between the sampling stations.

A total of 17 species of Copepoda were identified (Tab. II). The copepod assemblage of the Caravelas River estuary and the adjacent coastal region showed coastal and estuarine characteristics, and was numerically dominated by Paracalanus quasimodo Bowman, 1971, Acartia lilljeborgii Giesbrecht, 1889, Parvocalanus crassirostris (F. Dahl, 1894), and Temora turbinata (Dana, 1849). These species represented $68 \%$ of the total density of copepods collected (Tab. II). The abundant species changed during the sampling period. Paracalanus quasimodo (78\%) in the 2003 rainy season, $P$. crassirostris (20\%) in the 2003 dry season, and $A$. lilljeborgii in the rainy (31\%) and dry (25\%) seasons of 2004 were 


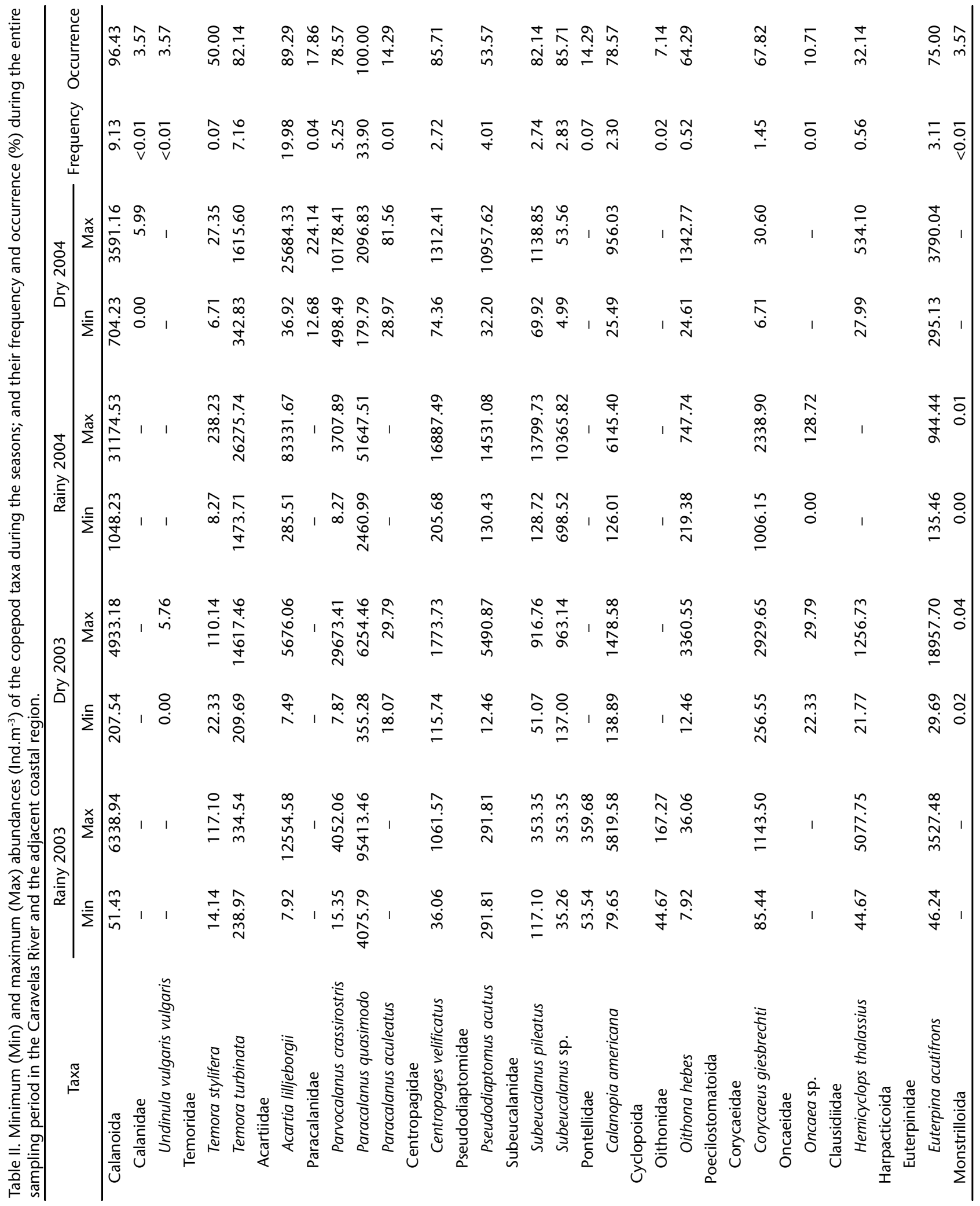


the most abundant species in the copepod assemblage at those times. The copepod community included inner-shelf and coastalwater species such as Hemicyclops thalassius Vervoort \& Ramirez, 1966 (with the exception of the 2004 rainy season), Oithona hebes Giesbrecht, 1891 and Pseudodiaptomus acutus (F. Dahl, 1894) (during the entire sampling period); marine-euryhaline species such as Euterpina acutifrons (Dana, 1847) and Corycaeus giesbrechti F. Dahl, 1894 (during the entire the sampling period); and tropical species such as Paracalanus aculeatus Giesbrecht, 1888 (during the 2003-2004 dry season) and Undinula vulgaris vulgaris (Dana, 1849) (during the 2003 dry season), outside the Caravelas River.

The results of multi-dimensional scaling from pairwise tests of ANOSIM performed during the sampling periods demonstrated that samples that were separated by different copepod assemblages were all significantly different from each other (ANOSIM significance level of sample statistic $=0.1 \%$ and global $\mathrm{R}=0.368$ ) (Fig. 8, Tab. III).

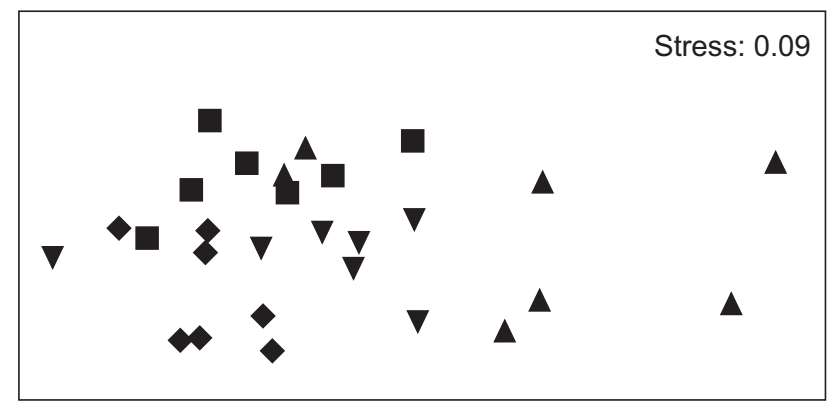

Figure 8. Multidimensional scaling plot of the copepod assemblage structure (ind. $\mathrm{m}^{-3}$ ) found during the 2-year sampling period (2003-2004) in the Caravelas River estuary and the adjacent coastal region (Bahia, Brazil): black triangle 2003 Rainy season, black inverted triangle 2003 Rainy season, black square 2004 Rainy season, black diamond 2004 Dry season.

Table III. ANOSIM analyses of similarity between groups of samples in the Caravelas River and the adjacent coastal region. (R) Strength of the difference between groups, $(p)$ probability of $R$ being attained by chance. The global result is the overall differences between groups.

\begin{tabular}{lcc}
\hline \multicolumn{1}{c}{ Groups } & $\mathrm{R}$ - Statistic & $\mathrm{p}$ \\
\hline Rainy/2003-Dry/2003 & 0.205 & 0.028 \\
Rainy/2003-Rainy/2004 & 0.437 & 0.004 \\
Rainy/2003-Dry/2004 & 0.594 & 0.001 \\
Dry/2003-Rainy/2004 & 0.315 & 0.009 \\
Dry/2003-Dry/2004 & 0.420 & 0.004 \\
Rainy/2004-Dry/2004 & 0.493 & 0.004 \\
\hline
\end{tabular}

In 2003, four taxa accounted for $80 \%$ of the similarity in the rainy season (center-right of the figure): Paracalanus quasimodo (40.48\%), C. giesbrechti (25.94\%), Calanopia americana
F. Dahl, 1894 (8.54\%), and Centropages velificatus (Oliveira, 1947) $(6.62 \%)$. In this sampling period, temperature (which was higher than $28^{\circ} \mathrm{C}$ at the two depths) was correlated with density (Pearson r-index, $\mathrm{R}=0.82$ at the surface and 0.91 near the bottom). In the dry season (center-left of the figure), on the other hand, temperature was positively correlated with salinity (between 32.44 and 34.51 at the two depths) and negatively correlated with density (Pearson $r$-index, $\mathrm{R}=-0.79$ at the surface and near the bottom). Paracalanus quasimodo, T. turbinata, Subeucalanus pileatus (Giesbrecht, 1888), C. giesbrechti, E. acutifrons, C. americana, and C. velificatus accounted for $16.13 \%, 15.35 \%, 10.64 \%, 9.86 \%$, $9.10 \%, 9.08 \%$, and $8.68 \%$ of internal similarities, respectively, in that order (Fig. 8).

During the 2004 rainy season (upper-left of the figure), P. quasimodo (15.56\%), T. turbinata (14.82\%), A. lilljeborgii (13.69\%), C. velificatus (12.31\%), S. pileatus (11.75\%), and C. americana $(8.26 \%)$ were the main taxa contributing to the delimitation of this sample group. During this sampling period, the environmental variables showed no significant correlation with the copepod community ( $\mathrm{p}<0.05)$. In the 2004 dry season (center and below-left of the figure), E. acutifrons, $P$. crassirostris, T. turbinata, P. quasimodo, A. lilljeborgii, and O. hebes were the main taxa responsible for the delimitation of this sampling group, accounting for $14.40 \%, 14.20 \%, 13.82 \%, 12.91 \%$, $11.61 \%$ and $9.02 \%$ of internal similarities respectively, in that order (Fig. 8), with the temperature (ranging from 25.4 to 26.9 at the two depths) negatively correlated with density (Pearson $r$-index, $\mathrm{R}=-0.79$ at the surface). The dissolved oxygen and Chlorophyll $a$ showed no significant correlation with the copepod community during the entire sampling period.

Copepod assemblage structure did not show significant differences between the sampling stations (ANOSIM significance level of sample statistic $=27.2 \%$ and global $\mathrm{R}=0.037$ ) of the Caravelas River estuary and the adjacent coastal region.

The diversity index $\left(\mathrm{H}^{\prime}\right)$ varied between 0.11 (station $\mathrm{P} 4$ ) in 2003 to 2.39 (station P3) in 2004 during the rainy season, and between 1.40 (station P2) to 2.61 (station P5) in 2004 during the dry season (Fig. 9). The lowest diversities were observed during the rainy seasons of both years (rainy 2003 - mean: 0.70, S.D.: 0.61; and rainy $2004-$ mean: 1.65 , S.D.: 0.54). The diversity index at stations P1, P2 (in the estuarine zone of the Caravelas River) and P7 (located in the adjacent coastal region of the Caravelas River estuary to the north) was high when compared with the other stations. The lowest evenness (J) values (0.05 in the 2003 rainy season and 0.43 in the 2004 dry season) were found at station P3, located in the adjacent coastal region; and the highest evenness values ( 0.85 in the 2004 rainy season and 0.79 in the 2004 dry season) were recorded at stations P3 and P5 (located in the adjacent coastal region to the south). Both species richness and diversity increased during the dry season in the estuarine zone of the Caravelas River, and to the north in the adjacent coastal region in both sampling periods. 


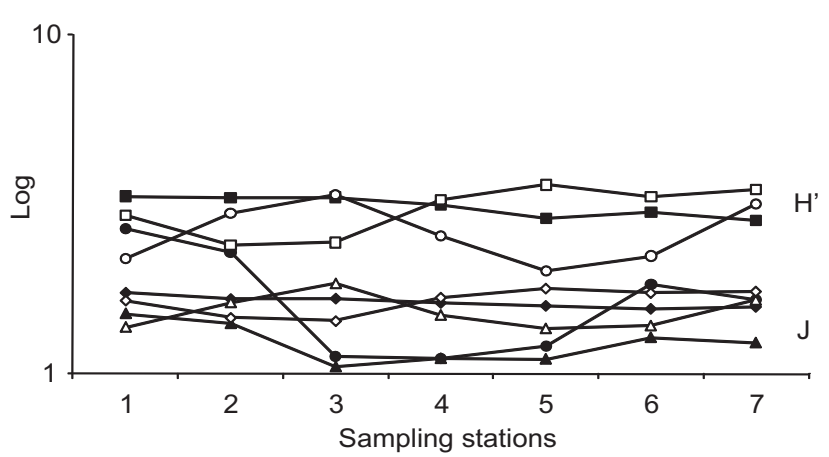

Figure 9. Diversity index $\left(\mathrm{H}^{\prime}\right)$ and evenness $(\mathrm{J})$ at sampling stations on the inner shelf adjacent to Camamu Bay during the 2-year sampling period (black - 2003 and open - 2004): circle - H' (Rainy season), square $-\mathrm{H}^{\prime}$ (Dry season), triangle - J (Rainy season), diamond - J (Dry season).

\section{DISCUSSION}

The Caravelas River estuary and the adjacent coastal region are located on the northeast coast of Brazil, influenced by the warm, nutrient-poor water of the Brazil Current (BRANDINI et al. 1997). The shelf and open ocean off northeast Brazil are largely affected by two water masses: the Tropical (TW) and the South Atlantic Central Waters (SACW) (Castro \& Miranda 1998, Neumann-LeITão et al. 1999).

According to the results of this study, the oceanographic structure of the Caravelas River estuary and the adjacent coastal region is basically formed by the same water masses off the Brazilian coast, as described by Emilsson (1961), Stramma \& SchotT (1999) and da Silva et al. (2005). The Coastal Water (CW) of the Caravelas River estuary was observed over the continental shelf during the dry season of 2003, during the ebb-flood tide. Its influence continued during the rainy season of 2004, though on a smaller scale. This was an indication of the continental influence during the study period. The salinity values observed at the station inside the Caravelas Channel indicate a dilution of ocean water by continental water. This reduction in salinity extended to other sampling stations, due to the effect of the flood tide, which allows the inner waters of the Caravelas Channel to exit to the adjacent coastal areas. The continental influence on the spatial distribution of salinity was indicated by the presence of the Mixed Water (MW), which also dominated at the surface and near the bottom during the 2004 rainy season. This suggests the effect of the lack of atmospheric precipitation, as well as the action of wind, which can homogenize the water column. The TW was recorded at both depths in the 2003 rainy and 2004 dry seasons. The SACW was not recorded in this study: the water temperatures remained high $\left(>24.9^{\circ} \mathrm{C}\right)$.

Dissolved oxygen was more homogeneous, with the highest values in the adjacent coastal region. Chlorophyll $a$ values decreased at the stations in the Caravelas Channel toward the adjacent coastal region. These trends are related to the input of nutrients in the Caravelas Channel. The values observed are lower than those reported for estuarine areas such as the Paraíba do Sul River, and similar to those observed in the Cabrália coastal region (Bahia) (Ovalle et al. 1999).

The copepods showed seasonal variation, with the highest densities during the 2003-2004 rainy seasons. This pattern cannot be associated with a rainy season, because of the atypically low rainfall during the sampling. There was no distinct dry or rainy season in relation to the precipitation. In regards to the sampling stations, the Cluster Analysis separated those that had the lowest copepod density values, which are located at the north and south, in the adjacent coastal region. These stations are located near the 10-m isobath, far from the estuary influence. Biomass maxima due to coastal zooplankton species were restricted to a rather narrow band influenced by the Coastal Water, decreasing towards the outer shelf regardless of the season (Lopes et al. 2006).

The copepod community was characterized by the numerical predominance of the estuarine and estuarine/coastal copepods $P$. quasimodo, A. lilljeborgii, T.turbinata and $P$. crassirostris, which changed between the cruises. The presence of marine euryhaline and oceanic species was well characterized by the occurrence of E. acutifrons, C. giesbrechti, P. aculeatus and $U$. vulgaris vulgaris outside the Caravelas River estuary, as well as by the typical inner species $H$. thalassius.

Many copepod species may occur in the community, though generally only a few of them are dominant. These species may vary seasonally and spatially along the estuary, being influenced by freshwater and coastal inputs (STERza \& LOUREIRo FERNANDES 2006). It is widely recognized that zooplankton (copepod) abundance in shallow, tidal estuaries fluctuates considerably with time in relation to physical and chemical parameters (e.g., tidal height, salinity) due to tidal cycles (ArA 2004). In the present study, the temperature and salinity influenced the differences between the cruises in relation to the copepod community. The greater homogeneity of the dissolved-oxygen and Chlorophyll $a$ contents may have contributed to the lack of any significant correlation with the copepod community during the sampling period. The copepod community in the Caravelas River estuary is common in estuarine and coastal waters of the southeastern (DIAS 1994, Lopes et al. 1998, Ara 2004, Sterza \& Loureiro Fernandes 2006) and northeastern Brazilian coast (SILVA et al. 2003, 2004).

The seasonal variations of the environmental variables could be related to the abundance of nearly all the species, during the sampling, with the dominant species alternating. Paracalanus Boeck, 1865 is one of the most important genera in the neritic region of the Brazilian coast, and according to Lopes et al. (1999) its distribution pattern mirrored that of the total copepods. Paracalanus quasimodo was the most abundant species during the 2003 rainy season, while $P$. crassirostris was abundant during the 2003 dry season. The dominant copepod $P$. quasimodo is an estuarine-coastal species that is common 
along the Brazilian east coast (BRAdFord-Grieve et al. 1999). Paracalanus quasimodo is marine-euryhaline, and usually occurs in areas with high salinities (Lopes et al. 1998). In the 2003 rainy season, the salinity values were higher than 36.8 (TW). Parvocalanus crassirostris was more abundant in the stations of the Caravelas Channel and in the adjacent coastal region (station P3), confirming its characteristic as an indicator species of coastal waters and reflecting the influence of estuarine outflow on the shelf. In Brazilian waters it can be observed only in coastal or mixed coastal and shelf waters (BJöRNBERG 1963). In the 2003 dry season, salinities were lower than 34.5 (CW).

In the seasons when the density of members of the family Paracalanidae decreased, A. lilljeborgii was the dominant species. Acartia lilljeborgii occurred in the entire study area and was abundant during 2004, mainly in the rainy season, when salinity remained below 35.2 (CW and MW). Acartia lilljeborgii is a marine-estuarine species, and has been the most abundant Acartia Dana, 1846 species in Brazilian estuaries (Lopes 1994), mainly in the middle and lower zones. Species of Acartia are indicators of coastal waters, and are often dominant among the copepods in the warm coastal and estuarine waters of higher salinity in Brazil (LOPEs 1994). Acartia lilljeborgii and P. crassirostris appear in Brazilian estuaries from the Amazon River up to $25^{\circ}$ S (LOPES 1994). A similar alternation between species of the genera Acartia and Paracalanus was also observed in Magdalena Bay (Mexico) by López-Ibarra \& Palomares-García (2006) and other authors in the region of the Baja California Peninsula (Mexico).

The copepod T. turbinata was observed at the Caravelas River estuary and the adjacent coastal region. During the 2003 rainy season, this species was present at only two stations located in the estuarine zone of the Caravelas River (stations P1 and P2), having become present at all stations since the 2003 dry season. Temora turbinata occurred in higher concentrations $\left(>1,400\right.$ ind. $\left.\mathrm{m}^{-3}\right)$ during the 2004 rainy season, with high temperature $\left(26.2-27.9^{\circ} \mathrm{C}\right)$ and low salinity (32.4-35.2) in the $\mathrm{CW}$ and MW. Temora turbinata, which did not occur in northeastern Brazil before 1993 (ARAújo \& Montú 1993), now dominates several coastal areas and estuaries of Brazil. Although this dominance has been corelated with ship ballast water at ports on the Brazilian coast (ARA 2002), more studies are necessary to confirm this relationship.

The copepod community did not show spatial variation, although different assemblages occurred during the sampling period, with greater abundances and lower diversity occurring during the rainy season. Since the majority of the species are from coastal areas, the spatial distribution of their abundance is controlled by the temperature and salinity gradients, as observed by Lopes (1996), Sterza \& Loureiro Fernandes (2006) and DiAs \& BONECKER $(2008 \mathrm{a}, \mathrm{b})$ in estuarine regions of southern Brazil, and in other tropical regions (VILLATE et al. 1993). However, additional factors must be considered when evaluating the distribution and abundance of zooplankton. In order to achieve a more comprehensive understanding of the latter, future studies should also take suspended matter into consideration, because the environment under study is influenced by anthropogenic sources along its length.

On the basis of the results obtained in this study, we conclude that, in contrast with copepod density at each sampling station, the copepod community as a whole did not show spatial variation. On the other hand, the copepod community formed distinct assemblages during the sampling period, with greater abundances occurring during the rainy season. The temporal distribution of copepod abundance was controlled by temperature and salinity gradients.

\section{ACKNOWLEDGEMENTS}

This study was conducted in the Integrated Laboratory of Zooplankton and Ichthyoplankton, Department of Zoology, Institute of Biology, Federal University of Rio de Janeiro (UFRJ). It is part of a monitoring program of the Caravelas region developed by CEPEMAR Ltda. We thank the Aracruz Celulose S.A. for placing some of their zooplankton material at our disposal. We thank Janet W. Reid for improving the English text.

\section{LITERATURE CITED}

ANP. 2009. Relatório Técnico: avaliação e ações prioritárias para a conservação da biodiversidade das zonas costeira e marinha. Agência Nacional de Petróleo, Gás Natural e Biocombustíveis. Available online at: http://www.anp.gov. br/guias_r8/sismica_r8/Bibliografia/MMA2002.PDF [Accessed: 16/IV/2009].

Andrade, A.C.S. \& J.M.L. Dominguez. 2002. Informações geológico-geomorfológicas como subsídios à análise ambiental: o exemplo da planície costeira de Caravelas - Bahia. Boletim Paranaense de Geociências 51: 9-17.

Andrade, A.C.S.; J.M.L. Dominguez; L. Martin \& A.C.S.P. BitTencourt. 2003. Quaternary Evolution of the Caravelas Strandplain - Southern Bahia State - Brazil. Anais da Academia Brasileira de Ciências 75 (3): 357-382.

ArA, K. 2002. Temporal variability and production of Temora turbinata (Copepoda: Calanoida) in the Cananéia Lagoon estuarine system, São Paulo, Brazil. Scientia Marina 66: 399406.

Ara, K. 2004. Temporal Variability and Production of the Planktonic Copepod Community in the Cananéia Lagoon Estuarine System, São Paulo, Brazil. Zoological Studies 43 (2): 179-186.

Araújo, H. \& M. Montú. 1993. Novo registro de Temora turbinata (Dana, 1949) (Copepoda, Crustacea) para águas atlânticas. Nauplius 1: 89-90.

BJöRNBERG, T.K.S. 1963. On the marine free-living copepods off Brazil. Boletim do Instituto Oceanográfico 13 (1): 3-142.

Bradford-Grieve, J.M.; E.I. Markhaseva; C.E.F. Rocha \& B. Abiahy. 1999. Copepoda, p. 869-1098. In: D. Boltovskoy (Ed.). South Atlantic Zooplankton. Leiden, Backhuys Publishers, 1706p. 
Brandini, F.P.; R.M. Lopes; K.S. GutSeit; H.L. SPACH \& R. SASI. 1997. Planctonologia na plataforma continental do Brasil Diagnose e revisão bibliográfica. Curitiba, MMA/CIRM/ FEMAR, 196p.

Castro, B.M. \& L.B. Miranda. 1998. Physical oceanography of the western Atlantic continental shelf located between $4^{\circ} \mathrm{N}$ and $34^{\circ} \mathrm{S}$ : coastal segment $(4 \mathrm{~W})$. In: A.R. Robinson \& H.B. Kenneth (Eds). The Sea 11 (8): 209-251.

Da Silva, A.C.; M. AraúJo \& B. Bourlè. 2005. Variação sazonal da estrutura de massas de água na plataforma continental do Amazonas e área oceânica adjacente. Revista Brasileira de Geofísica 23 (2): 145-157.

DiAs, C.O. 1994. Distribuição e variação espaço-temporal dos copépodes na Baía do Espírito Santo (Vitória - E.S. - Brasil). Brazilian Archives of Biology and Technology 37: 929-949.

Dias, C.O. \& A.V. Araujo. 2006. Copepoda, p. 21-99. In: S.L.C. BONECKER (Ed.). Atlas do zooplâncton da região central da Zona Econômica Exclusiva. Rio de Janeiro, Museu Nacional, Série Livros/Documentos REVIZEE Score Central 21, 228p.

Dias, C.O. \& S.L.C. Bonecker. 2008a. Long-term study of zooplankton in the estuarine system of Ribeira Bay, near a power plant (Rio de Janeiro, Brazil). Hydrobiologia 614: 65-81.

DiAS, C.O. \& S.L.C. BONECKER. 2008b. Inter-annual Variability of Planktonic Copepods in a Tropical Bay in Southeastern Brazil. Brazilian Archives of Biology and Technology 51: 731-742.

Emilsson, I. 1961. The shelf and coastal waters off Southern Brazil. Boletim do Instituto Oceanográfico 11: 101-112

Frontier, S. 1981. Cálculo del error en el recuento de organismos zooplanctónicos, p. 163-167. In: D. Boltovsкoy (Ed.). Atlas del Zooplancton del Atlántico Sudoccidental y métodos de trabajo com el zooplancton marino. Mar del Plata, INIDEP, 936p.

Gaudy, R. 1963. Campagne du navire océanographique "Calypso" dans les eaux côtières du Brésil (Janvier-Fevrier, 1962): Copépodes pelagiques. Recueil des Travaux de la Station Marine d'Endoume 30 (45): 15-42.

LEÃo, Z.M. DE A.N. 1999. Abrolhos, BA. O complexo recifal mais extenso do Atlântico Sul, p. 345-359. In: C. Schobbenhaus; D.A. Campos; E.T. Queiroz; M. Winge \& M. Berbert-Born (Eds). Sítios geológicos e paleontológicos do Brasil I. 554p. Available online at: http://www.unb.br/ig/sigep/sitio090/ sitio090.htm [Accessed: 16/IV/2009].

LEÃo, Z.M. DE A.N. \& J.M.L. Dominguez. 2000. Tropical coast of Brazil. Marine Pollution Bulletin 41: 112-122.

Lopes, R.M. 1994. Zooplankton Distribution in the Guaraú River Estuary (South-eastern Brazil). Estuarine, Coastal and Shelf Science 39: 287-302.

LoPES, R.M. 1996. Hydrography and zooplankton community structure: A comparative study among estuaries of the JuréiaItatins Ecological Station (Southeastern Brazil). Nerítica 10: 27-40.
Lopes, R.M.; R. DO VALE \& F.P. BRANDINI. 1998. Composição, abundância e distribuição espacial do zooplâncton no complexo estuarino de Paranaguá durante o inverno de 1993 e o verão de 1994. Revista Brasileira de Oceanografia 46: 195-211.

Lopes, R.M.; F.P. Brandini \& S.A. Gaeta. 1999. Distribution patterns of epipelagic copepods off Rio de Janeiro (SE Brazil) in summer 1991/19992 and winter 1992. Hydrobiologia 411: 161-174.

Lopes, R.M.; M. Katsuragawa; J.F. Dias; M.A. Montú; J.H. Muelbert; C. Gorri \& F.P. Brandini. 2006. Zooplankton and ichthyoplankton distribution on the southern Brazilian shelf: an overview. Scientia Marina 70 (2): 189-202.

López-Ibarra, G.A. \& R. Palomares-García. 2006. Estructura de la comunidad de copépodos en Bahía Magdalena, México, durante El Niño 1997-1998. Revista de Biología Marina y Oceanografía 41 (1): 63-76.

LoRENZEN, C.J. 1967. Determination of chlorophyll and pheopigments: Spectrophotometric equations. Limnology and Oceanography 12: 343-346.

Magalhães, A.; R.M. Costa; T.H. Liang; L.C. Pereira \& M.J.S. RiBEIRO. 2006. Spatial and temporal distribution in density and biomass of two Pseudodiaptomus species (Copepoda: Calanoida) in the Caeté river estuary (Amazon, region North of Brazil). Brazilian Journal of Biology 66 (2): 421430.

McEwen, G.F.; M.W. Johnson \& T.R. Folsom. 1957. A statistical analysis of the performance of the Folsom plankton sample splitter, based upon test observations. Archives for Meteorology Geophysics and Bioclimatology 7: 502-527.

Marchioro, G.B.; M.A. Nunes; G.F. Dutra; R.L. De Moura \& P.G.P. Pereira. 2005. Avaliação dos impactos da exploração e produção de hidrocarbonetos no Banco dos Abrolhos e adjacências. Megadiversidade 1: 225-310.

Neumann-Leitão, S. 1995. Resenha literária sobre zooplâncton estuarino no Brasil. Trabalhos de Oceanografia da Universidade Federal de Pernambuco 23: 25-53.

Neumann-Leitão, S.; L.M. de O. Gusmão; T. DE A. Silva; D.A. DE Nascimento-Vieira \& A.P. Silva. 1999. Mesozooplankton biomass and diversity in coastal and oceanic waters off North-eastern Brazil. Archive of Fishery and Marine Research 47 (2/3): 153-165.

Nybakken, J.W. \& M.D. Bertness. 2005. Marine Biology. An Ecological Approach. San Francisco, Benjamin Cummings, $579 \mathrm{p}$

Ovalle, A.R.C.; C.E. Rezende; C.E.V. Carvalho; T.C. Jennerjahn \& V. Iттеккот. 1999. Nearshore water and sediment chemistry, influence of an adjacent small mangrove river system, Easthern Brazilian Coast. Geo-Marine Letters 19 (3): 179185.

Perissinotto, R.; C. Nozais; I.Kibirige \& A. Anandraj. 2003. Planktonic food webs and benthic-pelagic coupling in three South African temporarily-open estuaries. Acta Oecologica 24 (1): 307-316. 
Pielou, E.C. 1977. Mathematical Ecology. New York, John Wiley, 385p.

Rap. 2009. Rapid Assessment Program. Appendix 5 - List of crustacean species previously recorded from the Abrolhos region (including the nearby cost) indicating habitat, range within Brazil, and general distribution, p. 137-156. In: G. Dutra; G.R. Allen; T. Werner \& S.A. McKenna (Eds). A rapid marine biodiversity assessment of the Abrolhos Bank, Bahia, Brazil. Bulletin of Biological Assessment 38, 162p. Available online at: http://www.conservation.org.br/arquivos/MarineRAP38Bra.pdf [Accessed: 16/IV/2009].

Seguin, G. 1965. Contribution à la connaissance du plancton des eaux côtières du Brésil (copépodes et amphipodes exceptés) et comparaison avec celui du Sénégal (Campagne de la Calypso, Janv. - Feb.1962). Pelagos 2 (3): 7-44.

SHANnON, C.E. 1948. A mathematical theory of communication. Bell System Technical Journal 27: 379-423.

Shimode, S.; T. Toda \& T. KiKUCHI. 2006. Spatio-temporal changes in diversity and community structure of planktonic copepods in Sagami Bay, Japan. Marine Biology 148 (3): 181-197.

Silva, A.P.; S. Neumann-Leitão; R. Schwamborn; L.M. DE O. Gusmão
\& D.A. Do Nascimento-Vieira. 2003. Diel and seasonal changes in the macrozooplankton community of a tropical estuary in Northeastern Brazil. Revista Brasileira de Zoologia 20: 439-446.

Silva, A.P.; S. Neumann-Leitão; R. Schwamborn; L.M. de O. Gusmão \& T. DE A. SiLva. 2004. Mesozooplankton of an Impacted Bay in North Eastern Brazil. Brazilian Archives of Biology and Technology 47: 485-493.

Sterza, J.M. \& L. Loureiro Fernandes. 2006. Zooplankton community of the Vitória bay estuarine system (southeastern Brazil). Characterization during a three-year study. Brazilian Journal of Oceanography 54: 95-105.

Stramma, L. \& F. Sснотт. 1999. The mean Flow Field of the tropical Atlantic Ocean. Deep Sea Research II 46: 279-303.

Valentin, J.L. \& W.M. Monteiro-Ribas. 1993. Zooplankton community structure on the east-southeast Brazilian continental shelf $\left(18-23^{\circ} \mathrm{S}\right.$ latitude). Continental Shelf Research 13 (4): 407-424.

Villate, F.; A. Ruiz \& J. Franco. 1993. Summer zonation and development of zooplankton populations within a shallow mesotidal system: the estuary of Mundaka. Cahiers de Biologie Marine 34: 131-143.

Submitted: 23.I.2009; Accepted: 10.XII.2009.

Editorial responsibility: Paulo da Cunha Lana 